\title{
THE COLLAPSE OF LIBERATION RHETORIC: THE EISENHOWER ADMINISTRATION AND THE 1956 HUNGARIAN CRISIS ${ }^{1}$
}

\author{
GÜNTER BISCHOF \\ University of New Orleans, New Orleans, LA \\ USA
}

\begin{abstract}
This paper will analyze Eisenhower's policy towards Eastern Europe in general and towards Hungary in particular from the perspective of the gaping gulf between high-minded rhetoric and the political realities of the Cold War and the nuclear arms race. While the Eisenhower Administration sounded the high-faluting rhetoric of "liberation of captive peoples" from communism and engaged in the short-lived effort to launch a "Volunteer Freedom Corps" to undermine communism in Eastern Europe, the political reality was that uprisings against communism were not supported in East Germany in 1953, neither in Poland and Hungary in 1956.

The Cold War regimes in Central Europe, along with the establishment of deterrence strategy, made the cautious Eisenhower administration not dare actively support rebellions in Eastern Europe. The price of an escalation of conflict towards nuclear war was deemed too dangerous; no direct interventions were launched in the Soviet sphere of influence. The price the Eisenhower administration also had to pay was a loss of trust among the "captive peoples". Eisenhower's rhetoric was revealed to be only propaganda.
\end{abstract}

Keywords: Hungary, 1956, Eisenhower's foreign policy, Cold War, Eastern Europe, propaganda

\section{Introduction}

Let me make it clear from the beginning - I am a "post-revisionist" when it comes to Eisenhower historiography (Introduction in Bischof/Ambrose 1995/1). I consider the Eisenhower administration's failure to support the Hungarian revolution in the fall of 1956 after three years of crusading rhetoric and propaganda promises of "liberating captive peoples" as one of its biggest policy breakdowns. It was also a huge moral failure in terms of the promises of democracy by the Western world to be extended to the Soviet block. One cannot, however, speak of a "missed opportunity" in Hungary, as post-revisionists aver in cases of Eisenhower's failures to react more positively towards initiating an era of détente with the new Kremlin leadership after Stalin's death in 1953, or improving relations 
with Mao's China instead of constant pinpricks directed against Beijing over the offshore islands Quemoy and Matsu, or by supporting nationalist regimes in the decolonizing "Third World" (e.g., Vietnam, Egypt). The Eisenhower administration could have been bolder and recognized Hungarian neutrality, once Imre Nagy announced it on November 1, and pushed for other nations to recognize it. The Eisenhower Administration could also have kept its "propaganda attack dogs" in the Munich studios of "Radio Free Europe" on a tighter leash and insisted that they not incite revolution in the Soviet block and not encourage the insurrectionists in Hungary by intimating U.S. military help. Eisenhower was prudent, however, in not directly intervening in the Hungarian Revolution with military force, or on a lower scale augmenting CIA covert operations. The danger of escalation up the nuclear ladder was too big in the new age of limited nuclear and/or thermonuclear war, especially as the Suez crisis provided another flashpoint of growing East-West tensions and potential escalation towards nuclear war.

Overall, the rather harsh judgment by the fine Hungarian-born Cold War scholar John Lukacs seems not far off the mark when it comes to Ike's containment policies in general and his Hungarian policy in particular: "Eisenhower was devious rather than straightforward, ideology-ridden rather than pragmatic, governed by calculation rather by convictions" [emphasis added] (quoted in Bischof 2003, 104).

President Dwight D. Eisenhower's and Secretary of State John Foster Dulles' policy towards the Revolution in Hungary in late October 1956 grew out of longstanding frustrations and resentments in the right wing of the Republican Party with the twenty-year tenure of Democrats in the White House in general and President Harry S. Truman's "passive" Cold War containment strategy in particular. White House reactions to the uprising in Hungary reflected unresolved policies and ambiguous feelings between a public policy of "liberation of captive nations" and a private behind-the-scenes realization that military challenges to Soviet hegemony in its Eastern European sphere of influence might trigger a larger nuclear conflict. While Eisenhower "psychological warfare" (Osgood) and "rhetorical diplomacy" (Tudda) remained truculent until 1956, his actual Eastern European policy had come to the conclusion by as early as late 1953 that the United States would not "incite uprisings" behind the iron curtain, since military interventions in Soviet controlled territory were out of the question for fear of a larger conflict and the unleashing of "World War III". Eisenhower opted for a policy of liberation "by peaceful means", which was equal to "waiting for Godot", as people suspected then and know much better now. This inherent ambiguity between tough crusading rhetoric and cautious policy was not as clearly discernible at the time as it is today recognized by "post-revisionist" scholars of the Eisenhower Presidency. The Hungarian insurrectionists have never forgiven Eisenhower his failure to support them militarily against the Soviet intervention in early November 1956. 
They took the drum beat of pronouncements and promises of "liberation" and "rollback" emanating from Ike's "spy warriors" out of Radio Free Europe and Radio Liberty as a firm promise rather than crusading propaganda.

This paper will address two themes: first, the dilemma of forging an unambiguous and unified foreign policy in the sometimes seemingly anarchical domestic environment of American democracy, where numerous constituencies fight for influence in Washington and need to be pleased; secondly, the use of psychological warfare and covert operations as integral parts of U.S. foreign policy making in the global struggle to contain Soviet communism in the early Cold War. The importance of psychological warfare to Eisenhower's Cold War policies has been the focus of the most recent literature on the Eisenhower presidency.

\section{Domestic Context of Eisenhower's Policy vis-à-vis Communism}

Mark Kramer has rightly stressed the importance of "internal-external linkages" with regard to Soviet foreign policy formulation after Stalin's death in March 1953 (Kramer, parts 1-3). The same holds even more true for American foreign policy making, where numerous domestic influences and public opinion always need to be addressed. One contextual element studies on both Eisenhower's Cold War policies in general and his policy vis-à-vis the Soviet block in Eastern Europe have not sufficiently taken into account is the volatile climate emanating from the domestic "politics of anti-communism" and the traumatization of American politics in the early 1950s by fears of a domestic "red scare". The pressure of McCarthyism pushed the Republican Party to the right after Dewey's loss against Truman in 1948. McCarthy's cowed Eisenhower during the 1952 campaign with his attacks on his mentor George C. Marshall. The Republican stalwarts (among them Senators Robert Taft and William Knowland) castigated the Democrats by beating them over the head with the "sellout of Eastern Europe" in the Yalta agreements. Even though Dulles had personally detested communism for religious reasons for a long time, the domestic "politics of anti-communism" is the real backdrop to Dulles' promises of the "liberation of the captive peoples", written into the Republican campaign platform in 1952. On the campaign trail in August 1952 Dulles warned that the U.S. "must abandon the 'containment' policy $\ldots$ in addition to being immoral, [it] does not work. It snuffs out a resistance spirit within the captive peoples ..." (Tudda, 77). Such inflammatory rhetoric was not only an attack on Truman but also an appeal to the Polish voters of Chicago and Cleveland and Detroit to vote for "Ike".

Eisenhower himself used crusading rhetoric in his own campaign speeches. In August 1952 he told the American Legion: 


\begin{abstract}
We must tell the Kremlin that never shall we desist in our aid to every man and woman of those shackled lands who seeks refuge with us, any man who keeps burning among his own people the flame of freedom or who is dedicated to the liberation of his fellows (quoted in Horvath, 7).
\end{abstract}

Never, however, did Dulles or Eisenhower promise the use of force to liberate the captive peoples. They expected those peoples to liberate themselves, or hoped that one day the Soviet Union would relinquish them.

But since Eisenhower's policy vis-à-vis the fellow Republican McCarthy was not to "get into a pissing contest with that skunk" and "giving him enough rope to hang himself", the junior Senator from Wisconsin stayed on the attack in 1953 (Bischof, 1995/2). He tried to block Bohlen's appointment as ambassador to the Soviet Union and Conant's as high commissioner to West Germany in their hearings before the Senate Foreign Relations Committee. He sent the "junketeering gumshoes" Cohn and Shine to Europe to hunt for communist authors in America House libraries. He was searching for communists inside the State Department, the Army, and the CIA - which was like finding Belzebub inside the Vatican. Eisenhower also faced a right wing isolationist insurgency in his own party by those like McCarthy who wanted the Yalta Agreements officially repudiated, and by Senator Bricker who aimed at curbing executive authority with his amendment requiring Congressional approval of all executive agreements. There were communist spies in the American government before and during World War II, as we now know from the "Venona" transcripts. But McCarthy's populist apoplectic reaction to the communist threat within the U.S. polity came late, and he never uncovered a single spy. He was the master of arousing fear and alarming the masses (Morgan, xiv). With his attack on the Army and the subsequent Army-McCarthy hearings the Senator from Wisconsin was censured and finally did "hang himself".

But this is the context of a rabid Republican right wing putting enormous pressure on the new president to reverse Truman's containment policies in which Eisenhower unleashed his rhetorical "liberation" crusade and his covert operations and propaganda initiatives to "roll back" the iron curtain in 1953. The high point of these policies were during the first two years of his presidency when McCarthy was still a power to be reckoned with and hovered over all of Eisenhower's Cold War foreign policy actions. Eisenhower himself was an ideologue and, at times, revealed some of McCarthy's unrelenting anti-communism as, for example, when he told Churchill at the Bermuda meeting in December 1953:

... as regards the P.M.'s belief that there was a New Look in Soviet Policy, Russia was a woman of the streets and whether her dress was new, or just the old one patched up, it was certainly the same whore underneath. America intended to drive her off her present 'beat' into the back streets (Colville, 683 in Bischof/1995/1, 146). 
Of course, he did not live up to this promise during the East German and Pilsen revolt in 1953, nor in the Polish labor strikes or the Hungarian uprising in 1956.

Once McCarthy was censored, Eisenhower could slowly back off from such hardline anti-communist talk and embark on testing Soviet offers for peaceful coexistence in 1955 and agree to a summit meeting at Geneva after the signing of the Austrian treaty. The pressure from the Republican stalwarts snapping at his heels, in other words, was less intense by late 1956 during the Hungarian crisis and that is why he may have been even less inclined to test Soviet resolve by supporting Hungarian insurrectionists.

We should also keep in mind that in the midst of the dual Hungary/Suez crises in 1956 Eisenhower was running for reelection and therefore inclined to be even more cautious in his foreign policies (Ambrose, 347ff). The seasoned incumbent President did not need the Eastern European vote so badly anymore to win his reelection as he did in 1952 as a newcomer to presidential politics. In a November 2, 1956 letter to his friend "Swede" Hazlett, however, Eisenhower indicated that he was overwhelmed by the unfolding of the double crisis in Hungary and Suez in the final days of a presidential campaign:

\begin{abstract}
It became too difficult for me to keep in touch with the various items of information that pour constantly into Washington from Europe and the Mid East and at the same time carry on the hectic activities of actual campaigning (PDDE, XVII, 2354).
\end{abstract}

\title{
III. The International Background to Eisenhower's Policy towards Hungary
}

Recent studies by Peter Grose, Gregory Mitrovich, Scott Lucas, Kenneth Osgood and now the massive Habiliationsschrift by the young German scholar Bernd Stöver, make it abundantly clear that the "shadow war" of covert operations aiming at destabilizing Soviet influence in its Eastern European sphere already began under President Truman in 1947/48. Stöver has shown that the Americans took the template of undermining the Soviet sphere and "liberating" the populations enslaved under communism directly from Nazi policies against the Soviet Union. The genesis of postwar "rollback" of communism originates in the Nazi crusade against bolshevism (Stöver, 121 ff). Nobody else, but George F. Kennan, the Director of the State Department's influential Policy Planning Staff initiated an aggressive policy of "counterforce" - a revolutionary policy designed to undermine the Kremlin's hold over the satellites (written down in the basic memorandum NSC 20/4). The goal was to incite and support "Titoist heresies" in Eastern Europe. A "campaign of truth" was started by way of the new radio sta- 
tions "Radio Free Europe" and "Radio Liberty". In a massive "black propaganda" campaign, balloons were drifted across the iron curtain dropping millions of leaflets aiming at undermining the communist regimes with their demands for freedom. The CIA secretly financed the "Congress of Cultural Freedom" and its crusade among Western European intellectuals on the left, trying to inspire anti-communism and reduce anti-Americanism (Berghahn). The CIA began to recruit a future "foreign legion" type army from the displaced Eastern European refugees in Germany and Austria who hated communism. They were to be sent back into the Eastern European satellites as a guerilla force destined to incite rebellions. In 1948 the highly secret "Office of Policy Coordination" (OPC) was established in the State Department (in 1950 transferred to the CIA) under the former OSS-operative Frank Wisner to launch a more aggressive policy of psychological warfare against the Soviet sphere. In 1952 the OPC had a budget of 206 million dollars and operated 4,000 agents in Europe, however, without any dramatic results. Operations in Albania, for example, were betrayed by the British spies Philby and Maclean. In fact, due to these moles the Kremlin seemed to be better informed about OPC guerilla activities in Eastern Europe than most members of the Truman administration.

In 1951 Truman established the "Psychological Strategy Board" to coordinate the "psychological warfare" against the Kremlin. During a general review of these programs, the Truman administration came to the conclusion that all efforts to undermine or topple Soviet regimes had failed. Charles Bohlen proposed a toneddown future "strategy of rational hope" containing the Soviet Union, yet accepting co-existence with it, and abandoning the dangerous aggressive subversive actions in the Soviet sphere of influence that might unleash a larger conflict (Mitrovich, 83-121).

It is a supreme irony of history that at the moment in time when the Truman administration had to admit that its subversive guerilla strategy in the Soviet block had not produced recognizable successes, the Republican candidate Eisenhower called for an even more aggressive psychological warfare strategy, abandoning containment and ultimately "rolling back" communism. Part of the problem was the Truman's "shadow war" programs had been so highly secret that the Republican opposition (Eisenhower and Dulles included) did not know the full extent of it.

After his election victory, Eisenhower and Dulles unleashed their "liberation" strategy with reckless abandon. They revived the idea of a "Volunteer Freedom Corps" of Eastern European refugees to be sent into the Soviet bloc as guerillas. Again, the idea had originated during the Truman years. Republican Senator Henry Cabot Lodge had pushed the idea of such a VFC soon after the end of the war. In 1952 Congress had passed 100 million dollars towards the establishment of it (a Republican congressman from Wisconsin pushed this under the "Kersten 
Amendement"). Eisenhower actively supported the VFC until 1955 (Carafano). Little did the Republicans realize what OPC operatives like William Sloan Coffin had come to recognize in the DP-camps of Germany and Austria - these divisive refugees were more interested in the American dollars doled under the CIA, Marshall Plan and VFC programs than in actually putting their lives on the line fighting communism behind the iron curtain. The "United States Information Agency" was created as an independent propaganda agency. Radio broadcasts were boosted and balloon programs into the Soviet sphere were stepped up. An ideological warfare "campaign of truth" was unleashed to discredit communist ideology. The high level "Operations Coordinating Board" replaced Truman's "Psychological Strategy Board" to coordinate all psychological warfare initiatives. Eisenhower appointed C. D. Jackson as his quasi-"psychological warfare czar". Eisenhower's definition was all-inclusive: "Psychological warfare can be anything from the singing of a beautiful hymn up to the most extraordinary kind of physical sabotage" (letter to Dulles quoted in Osgood, 413). In the basic National Security Council document NSC 162/2 (replacing Truman's key document NSC 68), psychological warfare actually was added as an integral part of Eisenhower's "new look" national security policy (Osgood, 422ff).

After a long, critical and intense review process of America's basic alternatives between containment and rollback in "Operation Solarium" throughout the summer of 1953, NSC 162/2 was passed in October (Dockrill, 1996, 33-47). The inherent dilemmas of an aggressive "rhetorical diplomacy" hobbling more cautious actual behind-the-scenes policies became clearly visible here. The new Eisenhower Administration had been caught unprepared for both Stalin's surprising death in March 1953 and the East German uprising on June 17. No plans for such exigencies of "captive people" taking action into their own hands existed in Washington. Eisenhower sent food to the East Germans insurgents but did not further fire them up with propaganda, let alone American military support that might result in a shooting war with the Soviets.

At a moment when anti-Soviet sentiment seemed to be boiling over in the Soviet bloc, NSC 158 of late June 1953 advocated "rollback" with the provocation of insurrections against the communist regimes. But the larger national security strategy review NSC $162 / 2$ pulled back from such a dangerous course. While the military wanted to develop a more dynamic approach to undermining Soviet control in its bloc, including the "use of force", Eisenhower and Dulles pulled back from such escalation, fearing that nuclear war would result from it. The hard-won and sobering consensus in the NSC was: "The detachment of any major satellite from the Soviet bloc does not now appear feasible except by Soviet acquiescence or by war" [my emphasis] (quoted in Ostermann, 520). In the basic memorandum on U.S. policy vis-à-vis the Soviet satellites NSC 174 of December 1953, rollback was duly abandoned. Psychological warfare undermining Soviet control and 
"support the spirit of resistance" via propaganda initiatives were to be continued. But the "incitement of premature revolts" must be avoided, even though satellite regimes should be undermined and "conditions favorable to eventual liberation" should be promoted (Ostermann, 521; NSC 174 repr. in Békés et al., 34-53). Eisenhower still tried to square the circle.

No false hopes for U.S. military intervention must be aroused among captive peoples. In a progress report on NSC 174, the Operations Coordinating Board made this crystal clear on July 17, 1954:

The desire for liberation from Soviet domination is undoubtedly strong among the captive peoples, many of whom would welcome militant action to liberate them, even to the extent of resort to a war of liberation by the West. Neither the U.S. nor the free world countries are willing to take such extreme steps, nor is the U.S. prepared to undertake or foster activities which it would not back up with military support in the event of ruthless Soviet suppression and reprisals. Furthermore, our European allies are strongly against taking what they estimate to be provocative action. Consequently, the U.S. must limit its activities to a scope which is considered inadequate by at least the activists among the captive people and some of the emigrés [emphasis added] (quoted in Kovrig, 69).

By mid-1954, then, right after McCarthy's implosion, all that was left of Eisenhower's "liberation" policy was "liberation rhetoric", which, of course, continued to raise hopes among captive peoples. The cautious policy of no military support of insurrections or direct interventions in the Soviet bloc was firmly laid down. As this citation indicates, Eisenhower's advisors fully anticipated the disappointment of rebellious captive peoples and émigré communities as a result of its unwillingness to support "extreme steps" towards liberation. The President's special advisor Harold Stassen had observed in a discussion in the National Security Council in December 1953: "There was no course of action or plan which the US would follow in the event of a successful revolt by one of these countries against their Soviet masters" (quoted in Horvath, 16). No detailed plans for supporting liberation struggles, in a nutshell, foreshadowed the U.S. response to the Hungarian rebellion in 1956.

Still, President Eisenhower would keep up the din of public rhetoric, calling for the unlikely liberation of Eastern Europe and German reunification in major propaganda statements such as the "Atoms for Peace" speech in December 1953, and continued to do so during the Geneva Summit meeting of July 1955. Liberationists condemned Geneva, which seemed to disguise containment as liberation (Tudda, 93). John Foster Dulles warmly praised the lucky Austrian settlement in a television appearance and speculated that Austrian freedom would be contagious 
to her neighbors behind the iron curtain (Bischof/1995, 158). He grandiloquently predicted in Congressional hearings that Austrian neutrality "will open up a new frontier of freedom in Yugoslavia and also the first frontier of freedom with Hungary, and one can anticipate that it is going to lead these countries to want for themselves that which they see given to Austria" (quoted in Horvath, 20). After the signing of the Austrian treaty Dulles strongly held up neutrality à l'Autriche as a model for captive peoples to follow in order to be lured away from Soviet control.

These "schizophrenic policies" (Tudda, 93) of the Eisenhower administration continued into 1956. In his January "state of the union" address Eisenhower condemned the Soviets for their "grave injustices" in Eastern Europe, yet behind the scenes he continued to reject military liberation and continued to promote "peaceful" liberation with exile groups. Khrushchev's "secret speech" was "pure gold" (G. Kennan in Tudda, 95) for Eisenhower's propaganda crusade. Dulles resisted the temptation to encourage further revolts in Czechoslovakia and Poland after their suppression, tepidly insisting on "keeping alive the spirit of liberty in these people" but not wanting to instigate anything. The Dulles brothers vetoed a proposed Nixon visit to Eastern Europe as being "crazy" and too provocative. the NATO's North Atlantic Council further cautioned the Eisenhower Administration not to "substitute hope for reason" in the "thaw" of Khrushchev's sensational critique of Stalin's policies. The captive peoples should not be encouraged towards "futile rebellions", since the West was "not prepared to use force to liberate" them (Tudda, 95f).

In its basic review of Eastern European policy (NSC 5608) of early July 1956, the National Security Council continued its policy between active containment and passive liberation. A "deliberate policy of attempting to liberate satellite peoples by military force must be rejected". But propaganda and covert operations should be continued "to maintain the morale of anti-Soviet elements, to foster desired changes in Soviet-satellite relationships, and to maximize Soviet difficulties". Yet the U.S. "should not encourage premature action on their part which will bring upon them reprisals involving further terror and suppression". The NSC was fully aware that there was a fine line between supporting "passive resistance" and an "invitation to suicide" (NSC 5608 repr. in Békés, 119-128, here 127f).

The stage was set, then, for the U.S. and Western response to the Red Army's crushing of the Hungarian rebellion, particularly since it was further complicated by Western disunity over Suez (for the complex interplay between these two major crises see the essays in Heinemann/Wiggershaus). After the first Soviet intervention, Dulles in a telephone conversation with Ambassador to the United Nations Henry Cabot Lodge, worried on October 24 "that it will be said that here are the great moments and when they came and these fellows were ready to stand up 
and die, we were caught napping and doing nothing" [emphasis added] (FRUS, $\mathrm{XXV}, 273$ ). CIA director Allen Dulles speculated in the National Security Council meeting on October 26 that "Soviet intervention in Hungary may have been due to Soviet unwillingness to submit to a second humiliation after Poland" (FRUS, 1955-57, XXV, 296). After Moscow did not intervene in Poland after a summer of unrest, they may well have feared satellite dominoes beginning to fall in Hungary.

John Foster Dulles assured the Kremlin in a speech delivered to the Dallas World Affairs Council the next day that the U.S. did not look upon the satellites as "potential allies" (FRUS, 1955-57, XXV, 317f). He insisted that Ambassador Bohlen hand the relevant passage of this speech to the Kremlin bosses a couple of days later (FRUS, XXV, 1955-57, 328). Eisenhower, upon disarmament advisor Harold Stassen's suggestion, had urged Dulles in a telephone conversation the night before his Dallas speech to give such an assurance. The President's desire that if the satellites had a free choice, they would choose neutrality, was wishful thinking: "All we hope is that they have the same likes as Austria" [emphasis added] (Ostermann, 527f).

The lack of consensus behind the President's passive and restrained course of action in the face of the Red Army's gunning down Hungarian freedom fighters continued throughout the crisis. Voices in the CIA and the Pentagon advocated active support of the rebels (Ostermann, 528f). OPC's Frank Wisner was ready to launch his CIA operatives from Vienna and was in total despair over Washington's refusal to aid the rebels directly. His "Red Sox/Red Cap" program encouraging unrest apparently was ready to go. Some American airborne forces were mobilized outside of Munich for deployment in Budapest (Granville, 193), and there is oral history evidence that some American units got as far as the Vienna area (Vienna conference 2002). Eisenhower rejected two proposals to air drop arms to the Hungarians (Granville, 193). There would not be an American military intervention for which the rebels in Hungary fervently hoped.

Some émigré broadcasters from "Radio Free Europe" in Munich, whose scripts were not sufficiently vetted by their American superiors, overstepped their tightly controlled boundaries and incited the Hungarian rebels by arousing false hopes of Western military aid. As Johanna Granville has concluded after reviewing the RFE scripts:

While some broadcasts raised hopes of military aid, others discredited Nagy, praised Mindszenty, fomented hatred of ?VH men, gave misleading information about the U.N., created a false picture of the political situation (siding with Hungary and ostracizing the Soviet union), and otherwise distorted the news (Granville, 171). 
RFE seems the only American organization that did not tightly abide by the strictures of Eisenhower's passive response to the Hungarian rebellion. Hungarian rebels losing their lives as a result of their continued resistance against all odds due to such RFE encouragement was the real tragedy.

\section{Conclusion}

With new documents becoming available and with more distance from the Hungarian events of 1956, scholars have only become more critical of the Eisenhower administration's passivity during the Hungarian insurrection in spite of its continued liberation rhetoric. Washington "lacked a concrete plan of response should a satellite try to withdraw from the Warsaw Pact and appeal to U.S. aid", charges Johanna Granville (Granville, 194), following a critique that Harold Stassen had already made in the National Security Council in 1953. Hungary clearly revealed the inconsistencies of the Eisenhower/Dulles liberation policy between the poles of emphasizing caution and encouraging Titoism. Concludes British intelligence scholar Richard Aldrich: "The pathetic efforts of the Hungarian underground against the invading Soviet forces also exposed the stupidity of any marginal policy of stirring up trouble somewhere short of liberation" (Aldrich, 337). Berndt Stöver has observed that the 1953 redefinition of containment by the Eisenhower Administration made the transition from offensive containment to liberation policy fluid (Stöver, 187). Ever since 1953 the public perception in the United States and in Europe was that Eisenhower was committed to actively supporting liberation of the captive peoples. Both the caution in not committing to active support of liberation and the lack of a plan for how to respond to liberation struggles in the Soviet sphere once they erupted, gave the Eisenhower White House an aura of indecisiveness. In Hungary, Dulles and Eisenhower indeed were caught "napping". During the Polish and Hungarian crises of 1956, Eisenhower's continued his "bland wait-and-see policy" that had characterized his entire stance vis-à-vis Eastern Europe (Horvath, 32).

Chris Tudda relishes the ultimate irony:

In reality, when revolution came to Eastern Europe, liberation reaffirmed Truman's containment policy. The Eisenhower administration never intended to risk a war against the Soviet Union in order to free the captive peoples (Tudda, 101).

Truman's psychological warriors had already concluded correctly in 1952 that peaceful liberation of the Soviet bloc would take a long time, maybe a generation or more. An embarrassed Eisenhower had to learn the hard way again during the Hungarian crisis and henceforth toned back his empty liberation rhetoric. The out- 
come of this policy for the Hungarian rebels was tragic, as László Borhi has observed, for "the unwillingness of the United States to counter Soviet military action meant that the Hungarian quest for liberation was suicidal" (Borhi, 1999, 109).

\section{Select Bibliography}

Aldrich, Richard J. The Hidden Hand: Britain, America and Cold War Secret Intelligence. Woodstock-New York: The Overlook Press, 2001.

Ambrose, Stephen E. Eisenhower: The President. New York: Simon \& Schuster, 1984.

Ambrose, Stephen E. Ike's Spies: Eisenhower and the Espionage Establishment. Garden City, NY: Doubleday \& Co., 1981.

Békés, Csaba, Malcolm Byrne, János M. Rainer, eds. The 1956 Hungarian Revolution: A History in Doctuments (National Security Archives Cold War Readers). Budapest-New York: Central European University Press, 2002.

Bischof, Günter. "Eindämmung und Koexistenz oder 'Rollback' und Befreiung? Die Vereinigten Staaten, das Sowjetimperium und die Ungarkrise im Kalten Krieg, 1948-1956", in Die Ungarnkrise 1956 und Österreich, ed. Erwin A. Schmidl. Vienna-Cologne--Weimar: Böhlau, 2003, pp. 101-128.

Bischof, Günter and Saki Dockrill, eds. Cold War Respite: The Geneva Summit of 1955 (Eisenhower Center Studies on War and Peace). Baton Rouge-London: Louisiana State University Press, 2000.

Bischof, Günter. "Eisenhower, the Summit, and the Austrian Treaty, 1953-1955", in Eisenhower: A Centenary Assessment, ed. Günter Bischof and Stephen E. Ambrose (Eisenhower Center Studies on War and Peace). Baton Rouge-London: Louisiana State University Press, 1995 [=1995/1].

Bischof, Günter. "The Politics of Anti-Communism in the Executive Branch During the Early Cold War: Truman, Eisenhower and McCarthy(ism)", in Anti-Communism and McCarthyism in the United States (1946-1954): Essays on the Politics and Culture of the Cold War, ed. André Kaenel. Paris: Messene, 1995, pp. 53-77 [1995/2].

Borhi, László. Hungary in the Cold War 1945-1956: Between the United States and the Soviet Union. Budapest-New York: Central European University Press, 2004.

Borhi, László. "Liberation or Inaction? The United States and Hungary in 1956", in Die Ungarnkrise 1956 und Österreich, ed. Erwin A. Schmidl. Vienna-Cologne--Weimar: Böhlau, 2003, pp. 129-146.

Borhi, László. "Rollback, Liberation, Containment, or Inaction? U.S. Policy and Eastern Europe in the 1950s." In: Joumal of Cold War Studies, Vol. 1, No. 3 (Fall 1999): 67-110.

Boyle, Peter G. Eisenhower (Profiles in Power). Harlow: Pearson Longman, 2005.

Carafano, James Jay. "Mobilizing Europe's Stateless: America's Plan of a Cold War Army”, Journal of Cold War Studies, 1 (Spring 1990): 61-85.

Dockrill, Saki. "Ungarn 1956: Amerikanische Befreiung - Mythos oder Versagen?", in Das Internationale Krisenjahr 1956: Polen. Ungarn, Suez, ed. Winfried Heinemann and Norbert Wiggershaus (Beiträge zur Militärgeschichte). Munich: R. Oldenbourg, 1999, pp. 533-552.

Dockrill, Saki. Eisenhower's New-Look National Security Policy, 1953-61. Houndmills; Macmillan, 1996.

Foreign Relations of the United States, 1955-1957. Vol. XXV: Eastern Europe. Washington, D.C.: Government Printing Office, 1990 [cited as FRUS]. 
Granville, Johanna. The First Domino: International Decision Making during the Hungarian Crisis of 1956. College Station: Texas A \& M University Press, 2004.

Granville, Johanna. "Neutral Encounters of the Paranoid Kind: Austria's Reactions to the Hungarian Crisis of 1956", in Austrian Foreign Policy in Historical Context, ed. Günter Bischof, Anton Pelinka, Michael Gehler (=Contemporary Austrian Studies 14). New Brunswick-London: Transaction, 2006, pp, 143-169.

Grose, Peter. Operation Rollback: America's Secret War Behind the Iron Curtain. Boston: Houghton Mifflin Co, 2000.

Horvath, Rudolph R. "Cautious Politics: An Assessment of Eisenhower's Reaction to the Challenge of Hungary, 1952-1956." M.A. Thesis University of New Orleans 1996.

Kovrig, Bennett. Of Walls and Bridges: The United States and Eastern Europe. New York: New York University Press, 1991.

Kramer, Mark. "The Early Post-Stalin Succession Struggle and Upheavals in East-Central Europe: Internal-External Linkages in Soviet Policy Making", in: Journal of Cold War Studies. Vol. 1, No. 1-3 (Winter 1999): 3-55; (Spring 1999): 3-38; (Fall 1999): 3-66 [parts 1-3].

Lucas, Scott. Freedom's War: The American Crusade against the Soviet Union. New York: New York University Press, 1999.

Mitrovich, Gregory. Undermining the Kremlin: America's Strategy to Subvert the Soviet Bloc, 1947-1956. Ithaca: Cornell University Press, 2000.

Morgan, Ted. Reds: McCarthyism in Twentieth Century America. New York: Random House, 2003.

Osgood, Kennth A. "Form before Substance: Eisenhower's Commitment to Psychological Warfare and Negotiations with the Enemy", Diplomatic History 24 (Summer 2000): 405-433.

Ostermann, Christian. "Das Ende der 'Rollback'-Politik: Eisenhower, die amerikanische Osteuropapolitik und der Ungarn-Aufstand von 1956", in Das Internationale Krisenjahr 1956: Polen, Ungarn, Suez, ed. Winfried Heinemann and Norbert Wiggershaus (Beiträge zur Militärgeschichte 48). Munich: R. Oldenbourg, 1999, 515-532.

The Papers of Dwight David Eisenhower, Vol. XVII: The Presidency: The Middle Way. Ed. Louis Galambos and Daun Van Eee. Baltimore: Johns Hopkins University Press 1996 [cited as PDDE].

Stöver, Bernd. Die Befreiung vom Kommunismus: Amerikanische Liberation Policy im Kalten Krieg 1947-1991 (Zeithistorische Studien 22). Cologne-Weimar-Vienna: Böhlau, 2002.

Tudda, Chris. The Truth Is Our Weapon: The Rhetorical Diplomacy of Dwight D. Eisenhower and John Foster Dulles. Baton Rouge-London: Louisiana State University Press, 2006 [forthcoming]. 